\title{
Effects of rice husk ash and wollastonite incorporation on the physical and thermal properties of refractory ceramic composites
}

\section{Efeitos da incorporação de cinza da casca de arroz e wollastonita nas propriedades físicas e térmicas de compósitos cerâmicos refratários}

${ }^{1}$ Federal University of Pampa, Av. Tiarajú, 810, Ibirapuitã, CEP: 97546-550, Alegrete, RS, Brasil.

${ }^{2}$ Centro Universitário Ritter dos Reis, Av. Manoel Elias, 2001, Passo das Pedras, Porto Alegre, RS, Brasil.

e-mail: silvabdebora@gmail.com, ederlimarangon@gmail.com,marcotier@unipampa.com.br, anapg@unipampa.edu.br, eduardo.pachla@gmail.com.

\begin{abstract}
The main objective of this work was to evaluate the effects of rice husk ash and wollastonite microfibers incorporation, added per clay partial substituition, on physical and thermal properties of refractory ceramic composites. The raw materials characterization occurred with respect to their chemical composition (XRF), phase composition (XRD) and granulometry by laser. The composites were avaluated by physical properties - apparent porosity, bulk density, water absorption, linear retraction after sinterization and mass variation - and thermal properties - thermal conductivity and thermal shock. The rice husk ash used in the present work proved to have potential as a ceramic precursor in the development of refractories. The clay substitution per ash and the microfiber different percentages resulted in an increase in water absorption and apparent porosity and a reduction in the linear retraction. The increase in porosity suggests that the mullitization was insufficient. Regarding the thermal performance, the thermal conductivity was inversely proportional to the porosity and the microfiber percentage. In addition, the higher the thermal-shock temperature gradient the lower was the number of cycles resisted by the composites.
\end{abstract}

Keywords: rice husk ash, wollastonite, refractory ceramic composites, physical properties, thermal properties.

\section{RESUMO}

O principal objetivo deste trabalho foi avaliar os efeitos da incorporação de cinza da casca de arroz e microfibras de wollastonita, adicionadas por substituição parcial de argila, nas propriedades físicas e térmicas de compósitos cerâmicos refratários. As matérias-primas foram caracterizadas quanto à composição química (FRX), composição de fases (DRX) e granulometria por laser. Os compósitos foram avaliados pelas propriedades físicas - porosidade aparente, densidade aparente, absorção de água, retração linear após sinterização e variação de massa - e propriedades térmicas - condutividade térmica e choque térmico. A cinza da casca de arroz utilizada no presente trabalho provou ter potencial como precursor cerâmico no desenvolvimento de refratários. A substituição da argila pela cinza e pelos diferentes percentuais de microfibra resultou em um aumento da absorção de água e da porosidade aparente e uma redução na retração linear de queima. O aumento da porosidade sugere que a reação de mulitização foi insuficiente. No que concerne o desempenho térmico, a condutividade térmica foi inversamente proporcional à porosidade e ao percentual de microfibra. Ademais, quanto maior foi o gradiente de temperatura de choque-térmico menor foi o número de ciclos resistidos pelos compósitos.

Palavras-chave: cinza da casca de arroz, wollastonita, compósitos cerâmicos refratários, propriedades físicas, propriedades térmicas. 


\section{INTRODUCTION}

The majority of emerging countries, like Brazil, has agrobusiness as one of the economy main pillars. As a result, there is the generation of large amounts of agroindustrial waste, which in most cases do not have adequate disposal and end up contributing to the environment degradation [1]. In this scenary, rice is one of the most important cultures in the country. Globaly rice production were about 516.89 million tons in 2018 harvest according to AMIS [2], which generates in therms of rice husk (residues) about 100 million tons [3]. Rice husk (RH) has a high calorific value, about $16720 \mathrm{~kJ} / \mathrm{kg}$; therefore, it is an attractive source of biomass. However, when it goes through a burning process is generated a new residue, the rice husk ash (RHA) [4].

In this perspective, facing a sustainable thinking, several researchers have sought ways to reuse these by-products, using them as raw material for the production of other materials. It is a way to simultaneously provide a correct destination to these residues and reduce production costs $[5,6]$.

The rice husk ash properties depends on the burning technique used, between $550-800{ }^{\circ} \mathrm{C}$ the ash is rich in amourphous silica and at higher temperatures cristiline ashes are obtained, each ash type are better for certain applications [3]. The RHA in its amorphous form it is already known as an alternative source of silica since assumes pozzolanic properties $[7,8]$; it is resistant to chemical corrosion, temperature variations and presents low thermal conductivity, high melting point, low bulk density and high porosity. These characteristics make it an excellent co-product to be introduced in several spheres of industry such as electronics, cement and ceramics $[3,9,10]$. Regard to ceramic materials, the waste amount of any kind that can be used almost never transpass $10 \%$ by weight and the most notable effect besides the energy saving during the burning process are a bigger porosity, mechanical and shrinkage properties reduction [3].

In addition, it is known that wollastonite acts as a favorable factor for the improvement of mechanical strength, as well as reducing warpage and fracture faults and increasing resistance to thermal shock [11]. In the specific case of ceramics composed of silica and alumina, wollastonite diffuses rapidly with these materials at low temperatures, reducing thermal expansion and minimizing fractures and shrinkage [12].

In this context, the presente study aimed to develop low-cost and sustainable refractory ceramic composites by analyzing the effects of RHA and wollastonite incorportantion on its physicial and thermal properties.

\section{MATERIALS AND METHODS}

The raw materials used for the composites manufacture were an artificial refractory clay, RHA and wollastonite microfibers. The materials characterization occurred with respect to their chemical composition by X-ray fluorescence (XRF) on a Shimadzu XRF 1800 sequential spectrometer, by laser granulometry using a Mastersizer 2000 measurer and phase composition by X-ray diffraction (XRD) using a $2 \theta$ Philips brand X'pert MPD diffractometer. The XRD analysis went trought $\mathrm{X}$-pert Highscore and the ICSD database.

In order to analyze the composites physical properties, it was performed bulk density, water absorption and apparent porosity tests according to the standard guidelines NBR 16661 [13] and the linear retraction after the sintering process and mass variation were calculated according to Equation 1, where $\mathrm{Li}$ is the initial length $(\mathrm{mm})$ and $\mathrm{Lf}$ is the final length $(\mathrm{mm})$. Regard the thermal properties were analised the thermal conductivity according to ASTM C518 [14] using a thermal conductivity measurer model Fox 304-LaserComp. The thermal shock resistance (TSR) was calculated by the Equation 2 - where $\mathrm{A}$ is the number of the cycle where the first crack appeared (defined by visual inspection) and $\mathrm{B}$ is the number of cycles for total sample rupture - according to NBR 13202 [15]. It is important to highlight that with respect to the TSR were evaluated three differente heating temperature $\left(500{ }^{\circ} \mathrm{C}, 850^{\circ} \mathrm{C}\right.$ and $\left.1000{ }^{\circ} \mathrm{C}\right)$ and that the lower is the TSR value, the better is the material performance. Excluding XRD, in which were performed only one evaluation per formulation, it were used three representative samples to all analysis.

$$
\begin{gathered}
\mathrm{LRS}=\frac{\mathrm{Li}-\mathrm{Lf}}{\mathrm{Li}} \times 100 \\
T S R=\frac{A}{B}
\end{gathered}
$$

Table 1 presents the formulations nomenclature used and their respective contents of clay, RHA and microfibers. The RHA contents were selected according to [3], which suggests $10 \%$ in weight as an excellent percentage of residue utilization. The selection of microfibers percentual was to verify the composites behavior with different amounts of wollastonite. The specific refractory clay selected was because of its high amount of aluminum oxide that in combination with the RHA favor the mullitization reaction and presentes low concentration of iron oxide, which favors refractoriness. The composites 
fabrication occurred at a planetary mixer in two steps, both during three minutes each and at low speed. The first one in a dry way and the second one after the water incorporation. The water content used was $10 \%$, which, in previous analysis conferred a satisfactory plasticity. A universal testing equipment (INSTRON) were used to confer the samples shape by uniaxial pressing process, with a pressure of $35 \mathrm{MPa}$ in a male-female mold, that produces three samples at each pressing, with $150 \mathrm{~mm}$ long, $30 \mathrm{~mm}$ wide and $20 \mathrm{~mm}$ tall. After the shaping step the composites samples were dryed at a drying air oven in three different temperatures sequentially $\left(60{ }^{\circ} \mathrm{C}, 80^{\circ} \mathrm{C}\right.$ and $\left.105^{\circ} \mathrm{C}\right)$ until mass stabilization. The last temperature been set $24 \mathrm{~h}$ before the sintering process to guarantee a slow total water elimination. The samples sinterization was at $1000{ }^{\circ} \mathrm{C}$ in a ceramic fast firing furnace (INTI FL-1400). It was selected a three-step ramp as can be seeing at Figure 1. The cooling process occurred naturally.

Table 1: Nomenclature of formulations with their respective contents of clay, silica and microfibers

\begin{tabular}{cccc}
\hline Nomenclature & Fire clay (\%) & Silica* $\left.^{*} \mathbf{\%}\right)$ & Microfibers* $^{*}(\mathbf{\%})$ \\
\hline A & 100 & 0 & 0 \\
\hline AS10 & 90 & 10 & 0 \\
\hline AS10W5 & 85 & 10 & 5 \\
\hline AS10W10 & 80 & 10 & 10 \\
\hline AS10W20 & 70 & 10 & 20 \\
\hline
\end{tabular}

*weight substitution in relation to clay

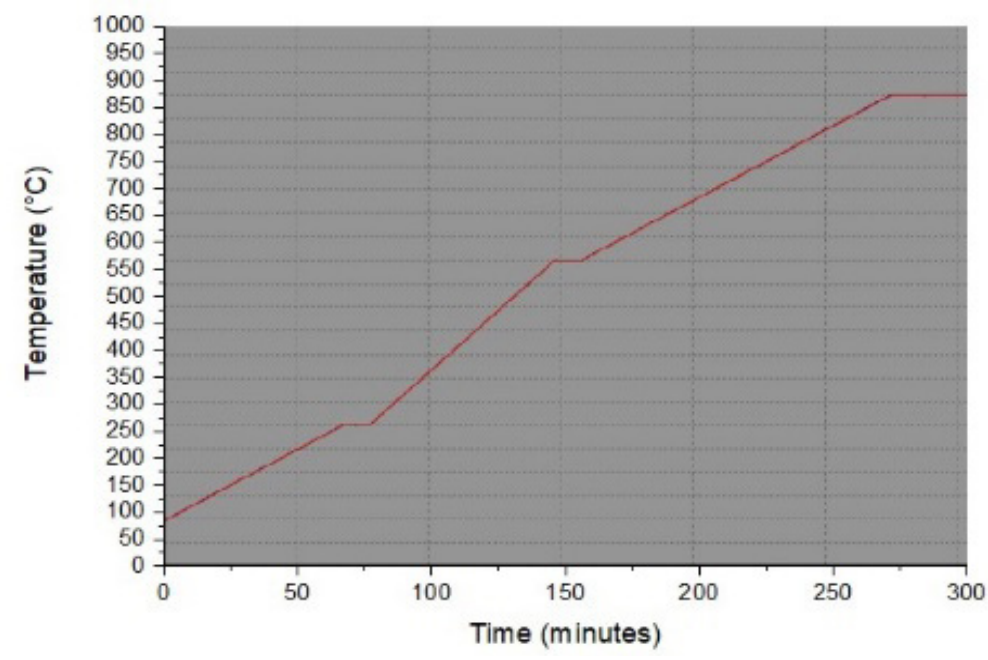

Figure 1: Heating ramp

\section{RESULTS AND DISCUSSION}

Table 2 presents the raw materials chemical compositions. Concerning to RHA the term 'other oxides' is related to potassium, calcium and carbon and concerning the clay, is related to potassium, iron, sulfur and carbon.

Table 2: Raw materials chemical compositions

\begin{tabular}{cc|cc|cc}
\hline & \multicolumn{2}{c}{ Refractory clay } & \multicolumn{2}{c}{ Microfibers } \\
\hline Element & Concentration (\%) & Element & Concentration (\%) & Element & Concentration (\%) \\
\hline $\mathrm{SiO}_{2}$ & 89,06 & $\mathrm{SiO}_{2}$ & 23,19 & $\mathrm{SiO}_{2}$ & 43,25 \\
\hline $\begin{array}{c}\text { Other oxi- } \\
\text { des }\end{array}$ & 10,94 & $\mathrm{Al}_{2} \mathrm{O}_{3}$ & 54,40 & $\mathrm{CaO}$ & 55,19 \\
\hline- & - & $\mathrm{F}_{2} \mathrm{O}_{3}$ & 4,98 & $\begin{array}{l}\text { Other } \\
\text { oxides }\end{array}$ & 1,59 \\
\hline- & - & $\begin{array}{c}\text { Other } \\
\text { oxides }\end{array}$ & 17,43 & & \\
\hline
\end{tabular}


Figure 2-A and B shows that RHA and microfibers presented a grain size larger than the clay. Furthermore, Figure 2-C shows that as substitutions occurred the amount of fine material decreased and the amount of coarse material increased. In addition, all formulations presented granulometric discontinuity, represented by the fall of the greater frequency peak. Figure 3 shows the XRD patterns. It is possible to observe at Figure 3-C that the clay it is a mostly crystalline material, with predominantly alumina phase. According to [16] the elevation of the baseline in $2 \theta=20^{\circ}$ and $2 \theta=30^{\circ}$ indicates the presence of amorphous material. Figure 3-A assay that RHA it is indeed a predominantly amorphous material, since it showed a wide diffraction peak centered at $2 \theta$ approximately equal to $22.5^{\circ}$ [17]. Figure 3-B presented calcium oxide and silicon oxide in crystalline form peaks. It is possible to state that the microfibers are mostly a crystalline material.
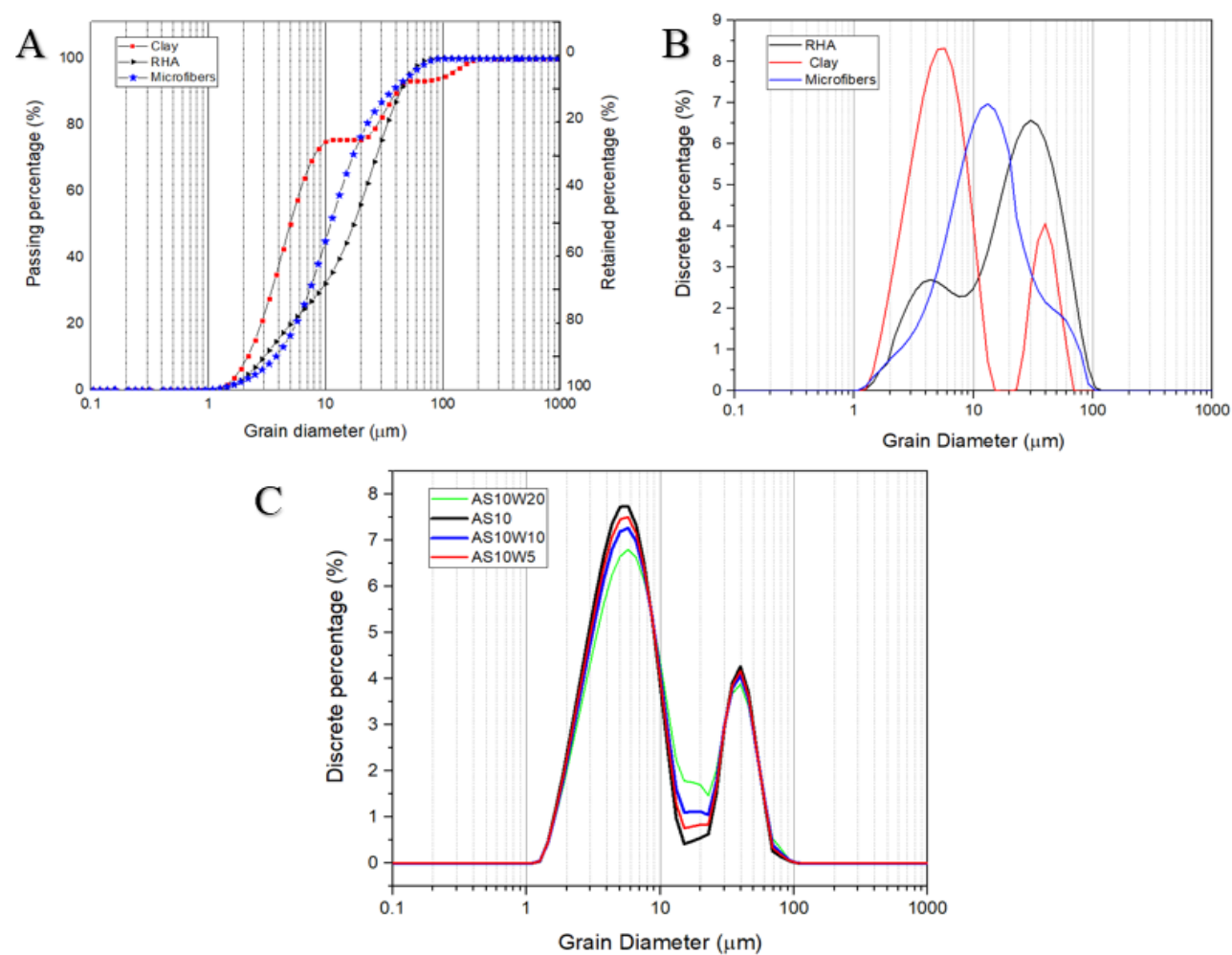

Figure 2: Granulometric curves (A) accumulated, (B) Discrete - raw materials, (C) Discrete - formulations.
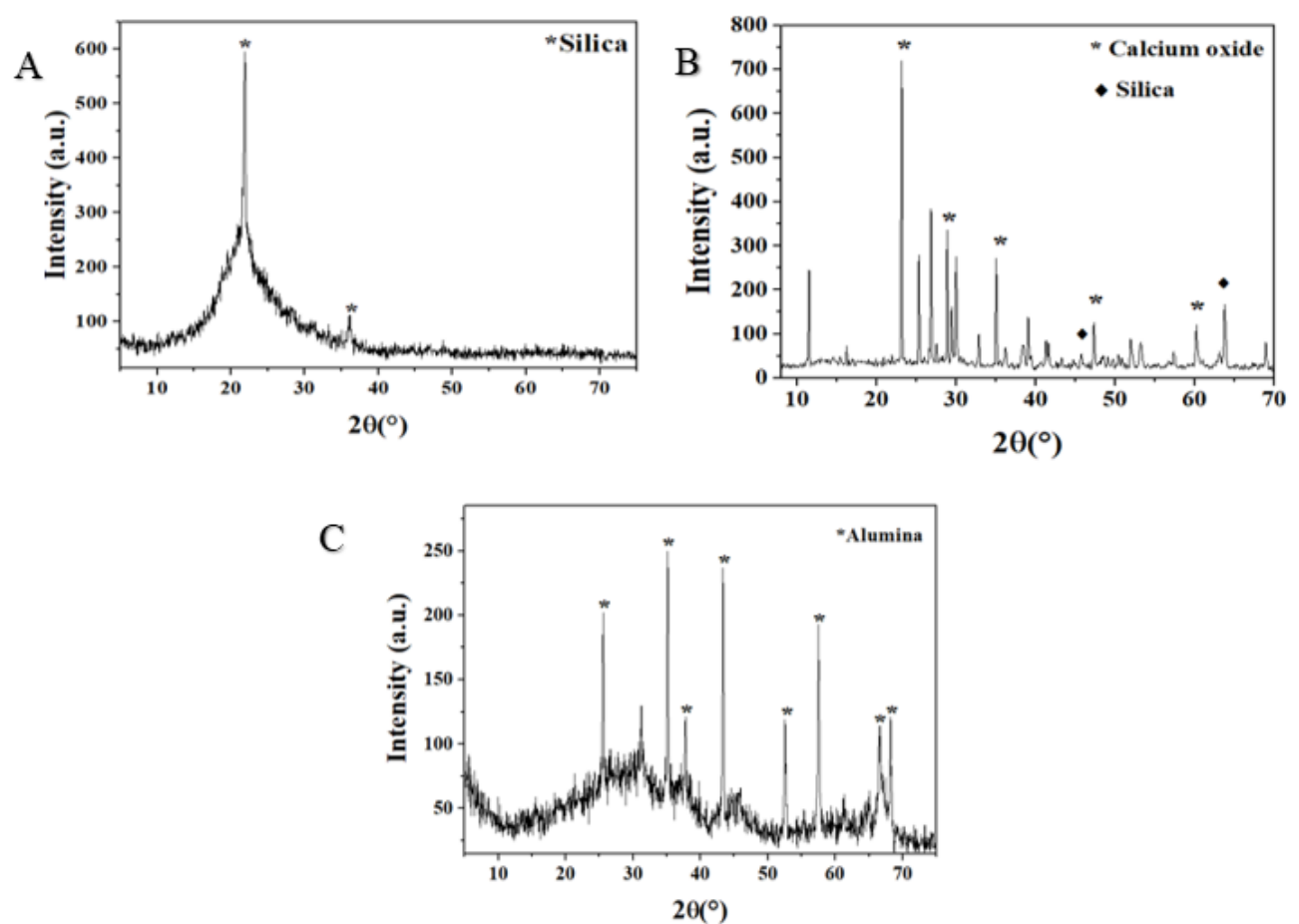

Figura 3: XRD pattern (A) RHA, (B) Wollastonite microfibers, (C) Refractory clay. 


\subsection{Physical Properties}

Table 3 shows the mean results and standard deviations of water absorption (WA), apparent porosity (AP) and bulk density (BD) of each of the five formulations. Each test used three representative samples per formulation. All variation coefficients (VC) stayed below 7\%, being, therefore, low coefficients. It is clear that the clay substitution per RHA and wollastonite microfibers generated an addition on the composites water absortion and apparent porosity. Vargas et al. [18] also observed the same behavior.

With regard to the AS10 formulation, the increase in porosity can be explained by the mullitization reaction and by the high porosity presented by RHA [3]. The mullitization comes from the mechanism of nucleation and growth. During the sintering stage, and subsequent temperature rise, the ions interdiffusion occurs at the interfaces between the alumina and silica elements. Most of the ions from the alumina diffuse into the silica portions to form a silico-aluminate liquid. As the temperature increases, the liquid is gradually enriched in aluminum ions until it reaches the stoichiometry of the mullite phase [19]. For this reason, some authors $[20,21,22]$ that used clays that already had a higher silica/alumina ratio, report a reduction in porosity of the material after the introduction of another silica source. This occurs because in this situation, where there is an excess of silica in relation to the stoichiometric proportion of the mullite, a part of the silica reacts with the alumina initiating the phase nucleation while another part becomes cristobalite and enters the existing pores decreasing the porosity of the material and the remainder remains in the form of quartz. However, when there is an excess of alumina a smaller amount of liquid phase is formed and consequently there is no excess of silica in the form of cristobalite to fill the material pores, therefore a greater porosity occurs $[20,21,22]$.

Table 3: Physical results

\begin{tabular}{c|c|c|c|c|c|c}
\hline Formulation & WA (\%) & VC (\%) & AP (\%) & VC (\%) & BD (\%) & VC (\%) \\
\hline A & $7,82 \pm 0,38$ & 4,82 & $12,99 \pm 0,47$ & 3,58 & $1,66 \pm 0,022$ & 1,32 \\
\hline AS10 & $10,23 \pm 0,66$ & 6,42 & $15,76 \pm 0,94$ & 5,98 & $1,54 \pm 0,014$ & 0,90 \\
\hline AS10W5 & $13,04 \pm 0,37$ & 2,87 & $19,19 \pm 0,61$ & 3,17 & $1,47 \pm 0,008$ & 0,54 \\
\hline AS10W10 & $14,43 \pm 0,47$ & 3,29 & $22,94 \pm 0,41$ & 1,81 & $1,59 \pm 0,050$ & 3,14 \\
\hline AS10W20 & $16,60 \pm 0,33$ & 2,01 & $25,45 \pm 1,09$ & 4,28 & $1,53 \pm 0,039$ & 2,55 \\
\hline
\end{tabular}

For samples AS10W5, AS10W10 and AS10W20 the increasing in porosity compared to formulation A is associated with two factors. The first one related to the multizination reaction explained above, and the second related to the granulometric aspects showed in Figura 2, this is, a thin material has been replaced by a coarser granulometry material which may have been responsible for the formation of voids. Jiang et al. [23] obtained a similiar result. The difference in grain size may also have influenced the porosity increase of the composites without microfibres; however, it was lower than the microfibre composites probably because the substitution content was lower. It is important to emphasise that porosity can directly influence the final properties of the material. A more porous material and consequently less dense, presents a lower mechanical performance, however, presents an improvement in properties like thermal conductivity.

Table 4 presents the LRS and mass variation (MV) results, both after the firing stage. It can be observed that formulations AS10W5, AS10W10 e AS10W20 showed a marked reduction in their LRS. The formulation AS, also presented a reduction in its LRS, however less prominent. It is also noted that such reduction occurred gradually as the clay was replaced by RHA and the microfibers (Figure 4). The MV was directly proportional to the retraction presented, that is to say, the formulation with greater MV was respectively the formulation of greater retraction and the formulation of lower MV showed the lowest retraction. Asar et al. [24] observed the same behavior. It is important to highlight that all the variation coefficients, with respect to the LRS remained well below $7 \%$ and as for the MV did not exceed $9 \%$. In addition, an Anova (Origin Pro) was used to evaluate if there was a statistically significant difference between the LRS values. All formulations were statistically diferent, which validates the action of the microfibers as a linear retraction reducing agent.

Table 4: Linear retraction after the sintering process

\begin{tabular}{ccccc}
\hline Formulation & LRS (\%) & VC (\%) & MV (\%) & VC (\%) \\
\hline A & $7,78 \pm 0,20$ & 2,55 & $4,73 \pm 0,21$ & 4,51 \\
\hline AS10 & $6,36 \pm 0,23$ & 3,68 & $4,63 \pm 0,14$ & 3,09 \\
\hline AS10W5 & $3,94 \pm 0,14$ & 3,53 & $3,88 \pm 0,12$ & 3,08 \\
\hline AS10W10 & $2,60 \pm 0,16$ & 6,02 & $3,05 \pm 0,22$ & 7,19 \\
\hline AS10W20 & $1,64 \pm 0,11$ & 6,74 & $2,55 \pm 0,23$ & 8,87 \\
\hline
\end{tabular}




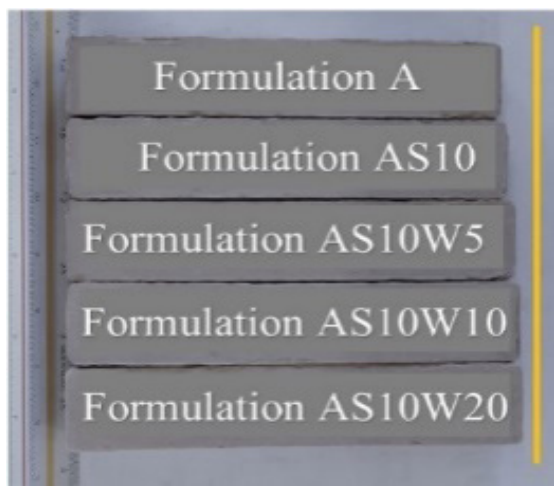

Figura 4: Comparison among the linear retraction of the composites

In addition, the density is also linked to the degree of retraction of the material. Consequently, a material that presents a more pronounced retraction consequently has a lower porosity and a higher densification [24, 25]. This fact complements the fact that formulations containing wollastonite microfibers, which is a material characterized by reducing retraction, have presented a lower retraction and a higher porosity. Similar bulk densities values were determined by Soliman et al.[26].

\subsection{Thermal Conductivity}

Table 5 shows the mean thermal conductivity results for either formulations considering three representative samples each. In order to evaluate if the clay substitution by RHA and by the different percentages of microfiber had influence on the thermal conductivity of the material, the analysis of variances was performed and the results are shown in Table 6 . It were observed by statistical analysis that there was no significant difference between the formulations A and the formulation AS10 and between the formulations AS10W5 and AS10W10.

By making an analysis between the formulations that were statistically different, it is possible to observe that as the substitution of the clay by the microfiber increased from 0 to 5 and to $20 \%$ there was a reduction in the thermal conductivity. Thermal conductivity of ceramic materials is closely related to their density and consequently to their porosity. However, other factors such as pore distribution, size and interconnectivity also influence and may vary according to the firing temperature $[27,28]$.

Table 5: Thermal conductivity results

\begin{tabular}{c|c|c}
\hline Formulation & Thermal conductivity (W/m.K) & VC (\%) \\
\hline A & $0,1659 \pm 0,0026$ & 1,57 \\
\hline AS10 & $0,1623 \pm 0,0025$ & 1,53 \\
\hline AS10W5 & $0,1559 \pm 0,0016$ & 1,03 \\
\hline AS10W10 & $0,1523 \pm 0,0003$ & 0,17 \\
\hline AS10W20 & $0,1446 \pm 0,0022$ & 1,54 \\
\hline
\end{tabular}

Table 6: Analysis of significant differences of the mean conductivities by the Tukey method

\begin{tabular}{ccc}
\hline Formulations & \multicolumn{2}{c}{ Is it statistically significant? } \\
\cline { 2 - 3 } & Yes & $\mathrm{X}$ \\
\hline A: AS10 & $\mathrm{X}$ \\
\hline A: AS10W5 & $\mathrm{X}$ \\
\hline A: AS10W10 & $\mathrm{X}$ \\
\hline A: AS10W20 & $\mathrm{X}$ \\
\hline AS10: AS10W5 & $\mathrm{X}$ \\
\hline AS10: AS10W10 & $\mathrm{X}$ \\
\hline AS10: AS10W20 & $\mathrm{X}$ \\
\hline AS10W5: AS10W10 & $\mathrm{X}$ \\
\hline AS10W5: AS10W20 & $\mathrm{X}$ \\
\hline AS10W10: AS10W20
\end{tabular}


In order to perform a joint analysis between apparent porosity and thermal conductivity was plotted Figure 5 graph. Through Figure 5 is evident that gradually as the porosity was increased the thermal conductivity decayed. The formulation A with the lowest porosity $(12.99 \%)$ presented the highest average thermal conductivity value $(0.165 \mathrm{~W} / \mathrm{mK})$, while the formulation AS10W20 with the highest porosity (25.45\%) showed the lowest thermal conductivity value $(0.1446 \mathrm{~W} / \mathrm{mK})$. However, it is necessary to be cautious when trying to reduce the thermal conductivity by raising the porosity, since such elevation generates a reduction in the mechanical resistance, which must be taken into account in the general behavior of the material. For this, it is importante trying to understand factors such as composition and microstructure [28].

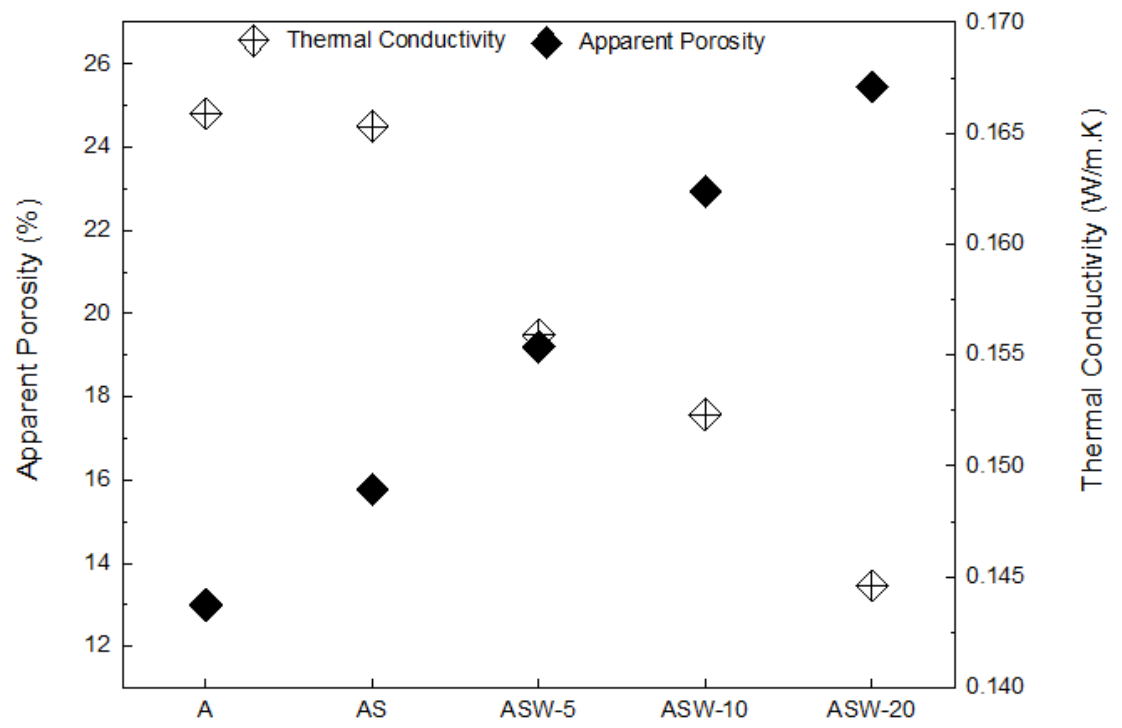

Figure 5: Correlation between AP and Thermal conductivity

\subsection{Thermal Shock}

Figure 6-A shows the maximum number of cycles resisted by each sample investigated at thermal shock fracture in the three heating temperature studied and considering the cooling temperature of $25{ }^{\circ} \mathrm{C}$. The tests used three representative samples per formulation for each heating temperature. It can be seeing that the formulation, which most generally resisted was the formulation $\mathrm{A}$, and that as the temperature difference was increased the amount of cycles resisted by the composites decresed. For the maximum heating temperature evaluated, which was $1000{ }^{\circ} \mathrm{C}$, all formulations withstood only one heating/cooling cycle, which demonstrates a low resistance to such a high thermal shock. In addition, other factors may have influenced, such as porosity and consequently mechanical resistance. In applications such as gas turbine engine and thermal protection structures, in which ceramic composites are used, some type of thermal shock will be involved. Therefore, the thermal shock resistance (TSR) is one of the primary factors to be evaluated with regard to the use of brittle materials in situations involving high temperatures [29]. Figure 6-B shows the relationship between the formulations and the mean TSR presented in each temperature ranges evaluated.

For the first range evaluated $\left(500{ }^{\circ} \mathrm{C}\right)$ the lowest TSR value (best performance) was presented by the formulation A and the highest TSR value (worse performance) by the formulation AS10W20. For the second range evaluated $\left(850^{\circ} \mathrm{C}\right)$ the lowest TSR value was also presented by the reference formulation A and the highest value by formulations AS10W10 and AS10W20, which had TSR equals to 1 . For the third evaluated range $\left(1000^{\circ} \mathrm{C}\right)$ all formulations had similar TSR results. The ideal temperature range for evaluating the refractories thermal shock resistance is not a consensus among the authors, this is, different temperatures evaluations can be found [30,31].

When a composite of brittle matrix is subjected to a thermal difference, the initial injury arises in the form of microcracks [32]. Figure 7 shows the samples before and after the thermal shock cycles, with emphasis on the type of fracture. It can be observed that samples A, AS10 and AS10W5 presented zigzag fractures, which is more visible in formulation A. This mode of fracture indicates that there was a higher total fracture energy since the cracks went through a longer path in the material [33]. The other formulations presented flat fracture surfaces. The type and number of cracks as well as the residual strength of the ceramic materials vary according to the way of entering the water, which may be laterally or longitudinally and this mode of sample insertion significantly influences the performance against thermal shock [34]. In presente work the samples inserction were longitudinally, this is, the same way Figure 7 presents it. In general, works that perform thermal shock by quenching, that is, heating to the maximum temperature and cooling in a cold-water bath, mechanical 
shocks occur and that this fact can also influence thermal shock results but that few researchers have studied the effect of this phenomenon [35].

A

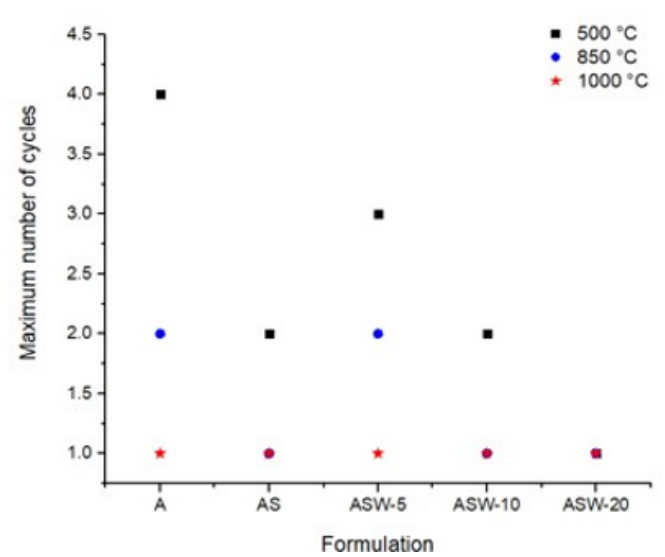

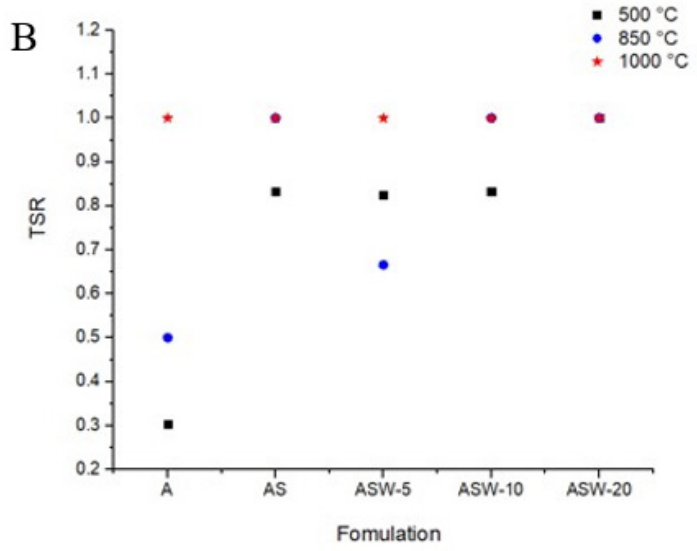

Figure 6: Maximum number of cycles for thermal shock fracture and thermal shock resistance

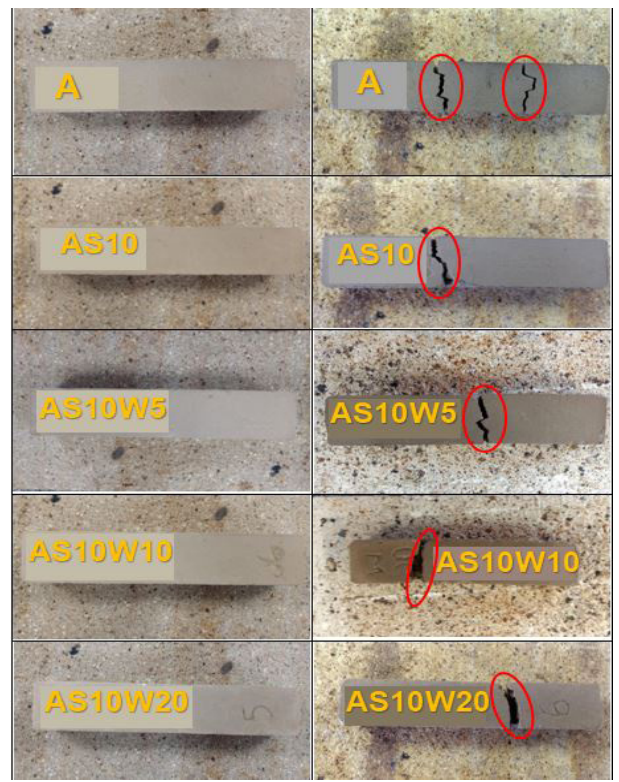

Figure 7: Samples before and after the thermal-shock cycles

\section{CONCLUSIONS}

This study examined the influence of RHA and wollastonite microfibers incorporation in substituion of the clay on the physical and thermal properties of refractory ceramic composites, aiming to develop sustainble materials. The following conclusions can be pointed:

- The agroindustrial residue (RHA) investigated in the present work proved to have potential to be used as ceramic precursor in the development of refractories, since it presented a high content of silicon oxide $\left(\mathrm{SiO}_{2}\right)$ mainly in the amorphous form, being, therefore, an excellent alternative as a silica source.

- Probably the mullitization reaction was insufficient, since there was an increase of the porosity, unlike other works that used larger silica/alumina ratio.

- The partial replacement of the refractory clay by RHA and by the different percentage of microfibers of wollastonite resulted in an increase on the porosity and water absorption, associated with the incomplete mullitization reaction and the granulometric aspects.

- The microfiber of wollastonite resulted in a marked reduction of the linear retraction of the composites; consequently, there was a lower densification of the same ones and a greater porosity. 
- The higher the thermal-shock temperature gradient the lower was the number of cycles resisted by the composites. The temperature of $1000{ }^{\circ} \mathrm{C}$ was excessively high and is not recommended for future works.

\section{ACKNOWLEGDMENTS}

The authors thank Silica Verde do Arroz Ltda. from the Pilecco Nobre Group and the Pontifical Catholic University of the State of Rio de Janeiro for supplying raw materials and the Coordination of Improvement of Higher Level Personnel in Brazil (CAPES) for financing (Finance Code 001) the research.

\section{BIBLIOGRAPHY}

[1] CHANDRASEKHAR, S. A. T. H. Y., SATYANARAYANA, K. G., PRAMADA, P. N., et al. N. Review processing, properties and applications of reactive silica from rice husk-an overview. Journal of materials science, v. 38, n. 15, pp. 3159-3168, 2003.

[2] AMIS, Agricultural Market Information System. http://www.amis-outlook.org/. Acessed in 05/15/2019.

[3] ANDREOLA, F., BARBIERI, L., BONDIOLI, F., et al. Valorization of rice husk ash as secondary raw material in the ceramic industry. In Proc. 10th Int. Conference of European Ceramic Society (ECERS), Baden-Baden, Germany, v. 1798, 2007.

[4] DELLA, V. P., KUHN, I., HOTZA, D. Reciclagem de resíduos agroindustriais: cinza de casca de arroz como fonte alternativa de sílica. Revista Cerâmica Industrial, pp. 22-25, 2005.

[5] MENEZES, R. R., NETO, E. F., FERNANDES, M. C., et al.Obtenção de mulita porosa a partir da sílica da casca de arroz e do acetato de alumínio. Revista Cerâmica, v. 54, n. 330, pp. 245-252, 2008.

[6] SERRA, M. F., CONCONI, M. S., GAUNA, M. R., et al. Mullite $\left(3 \mathrm{Al}_{2} \mathrm{O}_{3} \cdot 2 \mathrm{SiO}_{2}\right)$ ceramics obtained by reaction sintering of rice husk ash and alumina, phase evolution, sintering and microstructure. Journal of Asian Ceramic Societies, v. 4 , n. 1, pp. 61-67, 2016.

[7] ONOJAH, A. D., AGBENDEH, N. A., MBAKAAN, C. Rice husk ash refractory: the temperature dependent crystalline phase aspects. Journal: Ijrras, v. 15, n. 2, pp. 246-248, 2013.

[8] SEMBIRING, S., SIMANJUNTAK, W. X-ray Diffraction Phase Analyses of Mullite Derived from Rice Husk Silica. Makara Journal of Science, v. 16, n. 2, pp. 77-82, 2012.

[9] GONÇALVES, M. R. F, BERGMANN, C. P. Thermal insulators made with rice husk ashes: Production and correlation between properties and microstructure. Journal: Construction and Building Materials, v. 21, n. 12, pp. 2059-2065, 2007.

[10] FOLETTO, E. L., HOFFMAN, R., HOFFMAN, R. S., et al.Aplicabilidade das cinzas da casca de arroz. Revista Química Nova, v. 28, n. 6, pp. 1055, 2005.

[11] SINGH, V. K. Key Ceramics Materials. Department of Ceramic Engineering. Banaras Hindu University, 2003.

[12] SOUSA, L. L., SOUZA, A. D., FERNANDES, L., et al.Development of densification-resistant castable porous structures from in situ mullite. Journal: Ceramics International, v. 41, n. 8, pp. 9443-9454, 2015.

[13] ASSOCIAÇÃO BRASILEIRA DE NORMAS TÉCNICAS. NBR. 16661: Materiais refratários densos conformados-Determinação do volume aparente, volume aparente da parte sólida, densidade de massa aparente, densidade aparente da parte sólida, porosidade aparente e absorção. Rio de Janeiro, 2017.

[14] AMERICAN SOCIETY FOR TESTING AND MATERIALS. ASTM C518: Standard Test Method for Steady-State Thermal Transmission Properties by Means of the Heat Flow Meter Apparatus, 2015.

[15] ASSOCIAÇÃO BRASILEIRA DE NORMAS TÉCNICAS. NBR13202: Materiais refratários - Determinação do choque térmico pelo módulo de elasticidade residual. Rio de Janeiro, 2015.

[16] MEDEIROS, S. G., DUTRA, R. P. S., GRILO, J. P. F., et al. Preparação de compósitos alumina-mulita de baixo custo via sinterização reativa entre uma argila caulinítica da Paraíba e hidróxido de alumínio. Revista Cerâmica, v. 62, n. 363, pp. 266-271, 2016.

[17] LIOU, T. H. Preparation and characterization of nno-structured silica from rice husk. Journal: Materials Science and Engineering, v. A364, n.1-2, pp. 313-323, 2004. 
[18] VARGAS, F., RESTREPO, E., RODRIGUEZ, J. E., et al.Solid-state synthesis of mullite from spent catalysts for manufacturing refractory brick coatings. Journal: Ceramics International, v. 44, n. 4, pp. 3556-3562, 2018.

[19] MAGLIANO, M. V. M., PANDOLFELLI, V. C. Mulitização em refratários utilizando diferentes fontes precursoras. Revista Cerâmica, v. 56, pp. 368-375, 2010.

[20] BACCOUR, H., MEDHIOUB, M., JAMOUSSI, F., et al.Influence of firing temperature on the ceramic properties of Triassic clays from Tunisia. Journal of Materials Processing Technology, v. 209, n. 6, p. 2812-2817, 2009.

[21] HOSSAIN, S. S., MATHUR, L., SINGH, P. et al.Preparation of forsterite refractory using highly abundant amorphous rice husk silica for thermal insulation. Journal of Asian Ceramic Societies, in press, v. 5, n. 2, pp. 82-87, 2017

[22] SOUSA, L. L., SALOMÃO, R., ARANTES, V. L. Development and characterization of porous moldable refractory structures of the alumina-mullite-quartz system. Journal: Ceramics International, v. 43, n. 1, pp. 1362-1370, 2017.

[23] JIANG, W., LI, K., XIAO, J., et al.Effect of silica fiber on the mechanical and chemical behavior of alumina-based ceramic core material.Journal of Asian Ceramic Societies, v. 5, n. 4, p. 410-417, 2017.

[24] ASAR, N. V., KORKMAZ, T., GÜL, E. B. The effect of wollastonite incorporation on the linear firing shrinkage and flexural strength of dental aluminous core ceramics: A preliminary study. Journal: Materials \& Design, v. 31, n. 5, pp. 2540-2545, 2010.

[25] SOLIMAN, A. M., NEHDI, M. L. Effects of shrinkage reducing admixture and wollastonite microfiber on early-age behavior of ultra-high performance concrete. Journal: Cement and Concrete Composites, v. 46, p. 81-89, 2014.

[26] VERESHCHAGIN, V., SMIRENSKAYA, V. N., ANTIPINA, S. A., et al.Thermosilicate materials based on lime-silica binder and native wollastonite. Journal: Refractories and Industrial ceramics, v. 46, n. 1, p. 58-62, 2005.

[27] DONDI, M., MAZZANTI, F., PRINCIPI, P., et al. Thermal conductivity of clay bricks.Journal of materials in civil engineering, v. 16, n. 1, p. 8-14, 2004.

[28] TEN, J. G., ORTS, M. J., SABURIT, A., et al.Thermal conductivity of traditional ceramics. Part I: Influence of bulk density and firing temperature. Journal: Ceramics International, v. 36, n. 6, p. 1951-1959, 2010.

[29] DENG, Y., LI, W., SHAO, J., et al.Modeling the temperature-dependent non-steady state first matrix cracking stress for fiber ceramic matrix composites. Journal: Alloys and Compounds, v. 740, p. 987-996, 2018.

[30] TWITTY, A., RUSSELL-FLOYF, R. S., COOKE, R. G., et al.Thermal shock resistance of nextel/silica-zirconia ceramic-matrix composites manufactured by freeze-gelation. Journal of the European Ceramic Society, v. 15, n. 5, pp. 455-461, 1995.

[31] SALEKEEN, S., AMOAKO, J. N., MAHFUZ, H., et al. Mechanical property degradation of a Nicalon fiber reinforced SiNC ceramic matrix composite under thermal shock loading. Journal: Composite structures, v. 78, n. 4, pp. 477-485, 2007.

[32] BOCCACCINI, A. R. Predicting the thermal shock resistance of fiber reinforced brittle matrix composites. Journal: Scripta materialia, v. 38, n. 8, 1998.

[33] SOBROSA, F. Z., STOCHERO, N. P., MARANGON, E., et al.Development of refractory ceramics from residual silica derived from rice husk ash. Journal: Ceramics International, v. 43, n. 9, pp. 7142-7146, 2017.

[34] LI, D., LI, W., WANG, R., FANG, D. The effects of water entry postures on the thermal shock behavior of alumina. International Journal of Applied Ceramic Technology, v. 13, n. 1, pp. 56-60, 2016.

[35] KOU, H., LI, W., ZHANG, X., et al. Effects of mechanical shock on thermal shock behavior of ceramics in quenching experiments. Journal: Ceramics International, v. 43, n. 1, pp. 1584-1587, 2017.

\section{ORCID}

Débora Bretas Silva

Eduardo Cesar Pachla

Ederli Marangon

Marco Antonio Durlo Tier

Ana Paula Garcia https://orcid.org/0000-0003-1477-0746

https://orcid.org/0000-0003-0263-1562

https://orcid.org/0000-0003-0812-8095

https://orcid.org/0000-0002-0544-6234

https://orcid.org/0000-0002-2135-9747 